\title{
n-Hexane Hydrogenolysis Behavior of Alumina-Supported Palladium-Platinum Alloys
}

\author{
Monika Radlik $^{1} \cdot$ Krzysztof Matus $^{2} \cdot$ Zbigniew Karpiński $^{1}$
}

Received: 30 April 2019 / Accepted: 25 June 2019 / Published online: 6 July 2019

(C) The Author(s) 2019

\section{Abstract}

The behavior of alumina-supported palladium-platinum catalysts in the reaction of $n$-hexane hydrogenolysis was analyzed. The monometallic $\mathrm{Pt} / \mathrm{Al}_{2} \mathrm{O}_{3}$ catalyst showed much higher activity than the rest of catalysts. The relationship between the catalytic activity of $\mathrm{Pd}-\mathrm{Pt} / \mathrm{Al}_{2} \mathrm{O}_{3}$ catalysts and bulk Pd-Pt composition matched the accepted relation between the surface composition and bulk composition of Pd-Pt, confirming a high surface enrichment in palladium. A linear relation between the apparent activation energy and preexponential factor (compensation effect) suggests that the reaction mechanism is similar for all $\mathrm{Pd}-\mathrm{Pt}$ catalysts. However, after very high temperature of catalyst reduction $\left(\right.$ at $\left.600{ }^{\circ} \mathrm{C}\right)$, the behavior of monometallic $\mathrm{Pd} / \mathrm{Al}_{2} \mathrm{O}_{3}$ catalyst exhibited a considerable departure from the compensation plot, and drastic variations in $\mathrm{C}_{1}-\mathrm{C}_{5}$ products distribution. Such big changes are rationalized by assuming the transformation of $\mathrm{Pd} / \mathrm{Al}_{2} \mathrm{O}_{3}$ into $\mathrm{Pd}-\mathrm{Al}$ alloy, occurring at very high temperature of reduction. Product distribution of n-hexane hydrogenolysis for $\mathrm{Pt} / \mathrm{Al}_{2} \mathrm{O}_{3}$ differs from that of $\mathrm{Pd} / \mathrm{Al}_{2} \mathrm{O}_{3}$, showing more internal bond splitting than a terminal demethylation. However, bimetallic $\mathrm{Pd}-\mathrm{Pt} / \mathrm{Al}_{2} \mathrm{O}_{3}$ catalysts showed even more 'internal bond splitting' character than the $\mathrm{Pt} / \mathrm{Al}_{2} \mathrm{O}_{3}$. Reasons for this synergism and changes in the behavior of $\mathrm{Pd} /$ $\mathrm{Al}_{2} \mathrm{O}_{3}$ catalysts are analyzed in terms of an electronic interaction between metals and alumina support.

\section{Graphic Abstract}

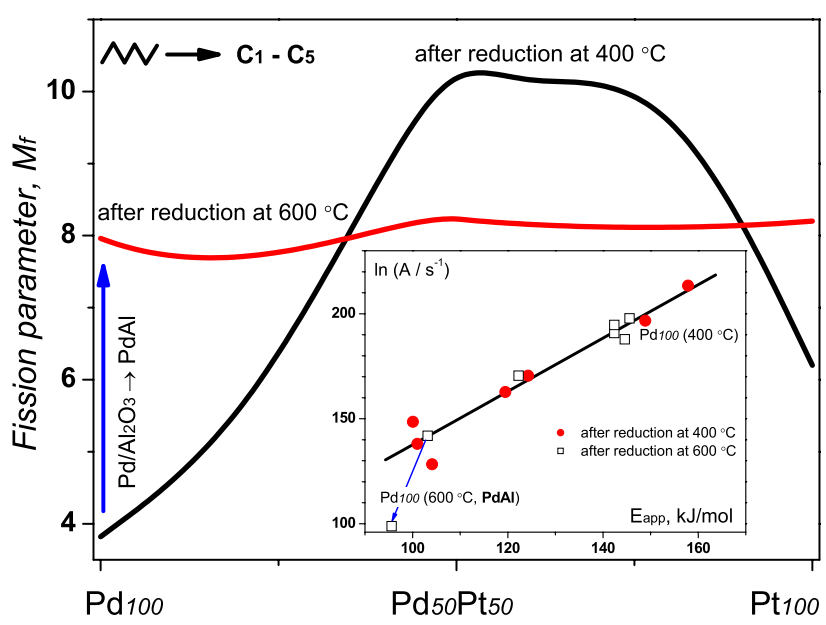

Keywords $\mathrm{Pd}-\mathrm{Pt} / \mathrm{Al}_{2} \mathrm{O}_{3} \cdot \mathrm{n}$-Hexane hydrogenolysis $\cdot$ Effect of alloying $\cdot$ Effect of catalyst reduction temperature . Compensation effect $\cdot$ Hydrogenolysis pattern

Electronic supplementary material The online version of this article (https://doi.org/10.1007/s10562-019-02887-4) contains supplementary material, which is available to authorized users.

Extended author information available on the last page of the article 


\section{Introduction}

Technological superiority of several Pt-based alloy catalysts in naphtha reforming, e.g., Pt-Sn, Pt-Ru, Pt-Ir, $\mathrm{Pt}-\mathrm{Rh}$ resulted in a large number of patents, source papers, reviews, and monographs (e.g. [1]). Introduction of a second metal to platinum often leads to a higher catalytic activity, better selectivity toward desired products (e.g. isomeric or aromatic compounds) and an increased catalyst's life-time. More recent attention was focused on Pt-Pd alloy catalysts which showed a superior sulfur tolerance, compared to the behavior of monometallic Pt catalysts, supported on acidic supports such as zeolite H-Beta [2]. Recently, in a post-conference paper we reported results on the catalytic behavior of $\mathrm{Pd}-\mathrm{Pt} / \mathrm{Al}_{2} \mathrm{O}_{3}$ catalysts in the reaction of $n$-hexane conversion [3]. Our main attention was turned to the problems how to prepare well mixed Pd-Pt catalysts and how the conditions of catalyst pretreatment influence the alkane isomerization behavior. It appeared that a simple incipient impregnation of alumina with toluene solutions of acetyloacetonates of palladium and platinum yields reasonably well alloyed $\mathrm{Pd}-\mathrm{Pt} / \mathrm{Al}_{2} \mathrm{O}_{3}$ catalysts, whereas a similar preparation technique with the use of respective metal chlorides results in poorly mixed bimetallic catalysts and chloride retention in the alumina support. It appears that the interaction of both metal acetylacetonates takes places already in a toluene solution [4], similarly to the situation with $\mathrm{Pd}-\mathrm{Cu}$ acetylacetonates [5]. It leads to the situation that upon impregnation, palladium and platinum are deposited in a close vicinity to each other. The degree of Pd-Pt alloy homogeneity had a significant effect on the relations of catalytic activities and product selectivities with $\mathrm{Pd}-\mathrm{Pt}$ alloy composition. At that time the hydrogenolysis behavior was not practically considered. It was so because in contrast to fluid catalytic cracking on zeolites, the hydrogenolysis of alkanes by metals is not of great technological importance, although the structure sensitivity often found in this reaction had in the past great usefulness in showing how the structure of the surface of small metal (and alloy) particles depended on their size. In addition, a common knowledge that among the most important catalytic metals, palladium and platinum exhibit the lowest activity in alkane hydrogenolysis [6-9] restricted our interest mainly to the isomerization [3]. However, shortly thereafter we realized that it would also be interesting to consider the hydrogenolysis behavior of $\mathrm{Pd}-\mathrm{Pt} / \mathrm{Al}_{2} \mathrm{O}_{3}$ catalysts. Irrespective of the fact that both metals showed indeed quite low catalytic activity in alkane hydrogenolysis, they produced different patterns of hydrogenolysis products. On palladium, the major hydrogenolysis reaction is demethylation, whereas on platinum, apart from demethylation, secondary-secondary $\mathrm{C}-\mathrm{C}$ bond ruptures become important. [9-11]. It turned out rather unexpectedly that the introduction of palladium (i.e. the metal on which mainly runs demethylation) to platinum enhances the propensity for splitting internal $\mathrm{C}-\mathrm{C}$ bonds. This "synergistic effect" and the effect of high temperature reduction on the hydrogenolysis behavior of $\mathrm{Pd}-\mathrm{Pt} / \mathrm{Al}_{2} \mathrm{O}_{3}$ catalysts are reported and discussed in this paper.

\section{Experimental}

Catalyst preparation and characterization (TPR, $\mathrm{H}_{2}$ chemisorption, XRD and TEM) were described in our previous report [3]. Briefly, 1 wt\% of Pd-Pt/ $\gamma$-alumina (Sasol Puralox Scca, 150-200 mesh, surface area $200 \mathrm{~m}^{2} / \mathrm{g}$ ) catalysts were prepared by an incipient wetness impregnation of alumina with a mixture Pd and Pt bis-acetylacetonate precursors $\left(\mathrm{Pd}(\mathrm{acac})_{2}\right.$ and $\mathrm{Pt}(\mathrm{acac})_{2}$ from Sigma-Aldrich, 99\%) dissolved in toluene (analytical reagent from Chempur, Piekary Ślaskie, Poland. In further text, the catalysts are designed as $\operatorname{Pd} X \operatorname{Pt} Y$, where $X$ and $Y$ stand for atomic percentages of $\mathrm{Pd}$ and $\mathrm{Pt}$ in the metal phase.

Catalytic activity measurements were described in our previous report [3]. Briefly, the hydroconversion of n-hexane was conducted in a continuous-flow reaction glass system under atmospheric pressure. The partial pressure of n-hexane was $6.0 \mathrm{kPa}$, resulting in $\mathrm{H}_{2}$-to-hexane ratio $~ 16: 1$.

Turnover frequencies (TOFs) were calculated on the basis of the metal fraction exposed measured by pulse $\mathrm{H}_{2}$ chemisorption [3]. Product selectivities were calculated as the carbon percentage of $n$-hexane consumed in the formation of a designated product.

\section{Results and Discussion}

Characterization of $1 \mathrm{wt} \% \mathrm{Pd}-\mathrm{Pt} / \mathrm{Al}_{2} \mathrm{O}_{3}$ catalysts subjected to different reduction conditions was described elsewhere [3]. Table 1 exemplifies the most important results concerning metal dispersion data. The catalysts showed rather good metal dispersions, with metal particle sizes ca. $2 \mathrm{~nm}$, as measured by TEM, and small decrease in metal dispersion produced by catalyst reduction at higher temperatures (up to $600^{\circ} \mathrm{C}$ ). STEM-EDX data showed a relatively good degree of Pd-Pt alloying. Reasonable information about the composition of Pd-Pt alloy phases was assessed from catalytic data and was supported by STEM-EDX results. The relation between TOF and the Pd-Pt bulk composition exhibited a concave shape, characterized by a rather sharp decrease of TOF for Pt-rich alloys, and much milder changes for the rest of Pd-Pt alloys which showed very low catalytic activity. This relation, implying a high surface enrichment in palladium, matches the accepted relationship between the surface 
Table 1 Metal dispersion in $1 \mathrm{wt} \% \mathrm{Pd}-\mathrm{Pt} / \mathrm{Al}_{2} \mathrm{O}_{3}$ catalysts after reduction at $400{ }^{\circ} \mathrm{C}$ for $17 \mathrm{~h}$

\begin{tabular}{lll}
\hline Catalyst $^{\mathrm{a}}$ & $\mathrm{H} /(\mathrm{Pd}+\mathrm{Pt})^{\mathrm{b}}$ & $\mathrm{d}(\mathrm{nm})^{\mathrm{c}}$ \\
\hline Pd100 & 0.28 & $4.0\left(2.5^{\mathrm{d}}\right)$ \\
Pd80Pt20 & 0.234 & $4.8\left(2.6^{\mathrm{d}}\right)$ \\
Pd60Pt40 & 0.296 & $3.8\left(2.3^{\mathrm{d}}\right)$ \\
Pd50Pt50 & 0.334 & $3.4\left(2.4^{\mathrm{d}}\right)$ \\
Pd40Pt60 & 0.351 & $3.2\left(2.0^{\mathrm{d}}\right)$ \\
Pd20Pt80 & 0.395 & $2.8\left(1.5^{\mathrm{d}}\right)$ \\
Pt100 & 0.445 & $2.5\left(1.3^{\mathrm{d}}\right)$ \\
\hline
\end{tabular}

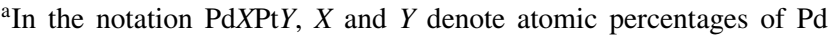
and $\mathrm{Pt}, X+Y=100(\%)$

${ }^{\mathrm{b}}$ Metal dispersion from hydrogen chemisorption (pulse method)

${ }^{c}$ Based on the relations: $d_{P d}(n m)=1.12 /(H / P d)$, from Ichikawa et al. [12], and $\mathrm{d}_{\mathrm{Pt}}=1.13 /(\mathrm{H} / \mathrm{Pt})$, from Rachmady and Vannice [13]

${ }^{\mathrm{d}}$ Numbers in the brackets show the results of TEM measurements

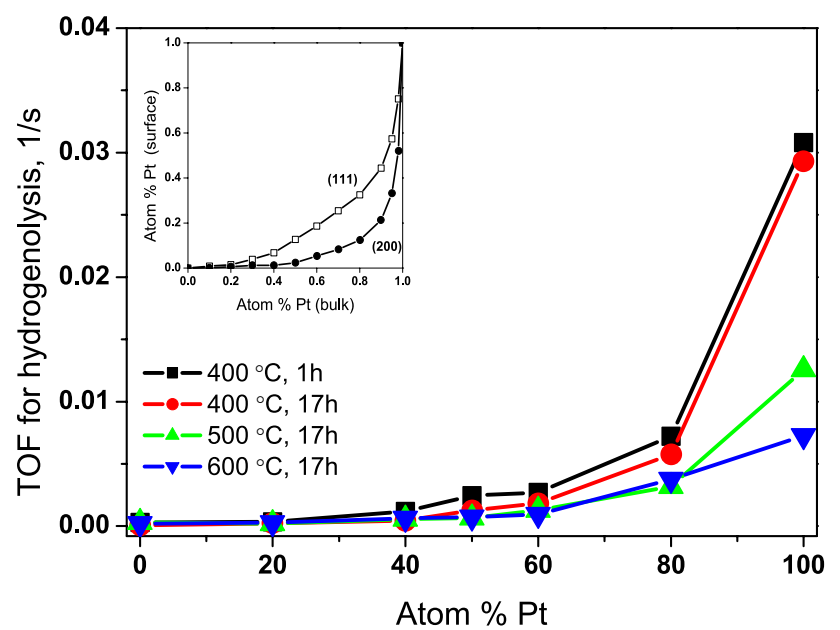

Fig. 1 Catalytic activity of $1 \mathrm{wt} \% \mathrm{Pd}-\mathrm{Pt} / \mathrm{Al}_{2} \mathrm{O}_{3}$ in the reaction of $\mathrm{n}$-hexane hydrogenolysis after different conditions of catalyst's reduction, indicated in the graph. Reaction temperature $291{ }^{\circ} \mathrm{C}$. Inset: the relation between surface and bulk composition of $\mathrm{Pd}-\mathrm{Pt}$ alloys adapted from Rousset et al. [14]

and bulk compositions of $\mathrm{Pd}-\mathrm{Pt}$ alloys [14]. $\mathrm{Pd} 100 / \mathrm{Al}_{2} \mathrm{O}_{3}$ showed higher than $\mathrm{Pt} 100 / \mathrm{Al}_{2} \mathrm{O}_{3}$ selectivity for isomerization, especially after reduction at higher temperatures, at 500 and $600{ }^{\circ} \mathrm{C}$. On alloying with Pt, the selectivity for isomerization was very high for nearly all bimetallic catalysts and showed a small synergistic effect for 20 at.\% Pt [3]. A similar synergy was found in neopentane isomerization carried out on silica-supported Pd-Pt alloys [15, 16].

All basic experimental data covering the catalytic behavior of $\mathrm{Pd}-\mathrm{Pt} / \mathrm{Al}_{2} \mathrm{O}_{3}$ catalysts in the reaction of n-hexane hydrogenolysis are collected in the Electronic Supporting Material (Tables 1-8 (ESM)), whereas the most important correlations will be presented graphically (Figs. 1, 2, 3,

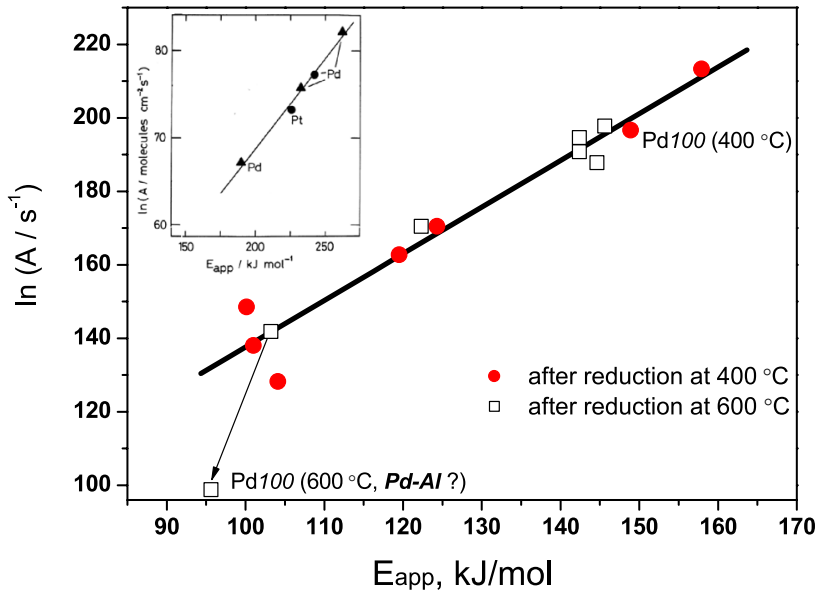

Fig. 2 Compensation plot for the hydrogenolysis of n-hexane on 1 wt $\% \mathrm{Pd}-\mathrm{Pt} / \mathrm{Al}_{2} \mathrm{O}_{3}$ catalysts. Red circles - catalysts reduced at $400{ }^{\circ} \mathrm{C}$ for $1 \mathrm{~h}$, open squares-catalysts reduced at $600{ }^{\circ} \mathrm{C}$ for $17 \mathrm{~h}$. Inset: compensation plot for ethane hydrogenolysis on silica-supported $\mathrm{Pt}$ and Pd catalysts adapted from Bond [18]

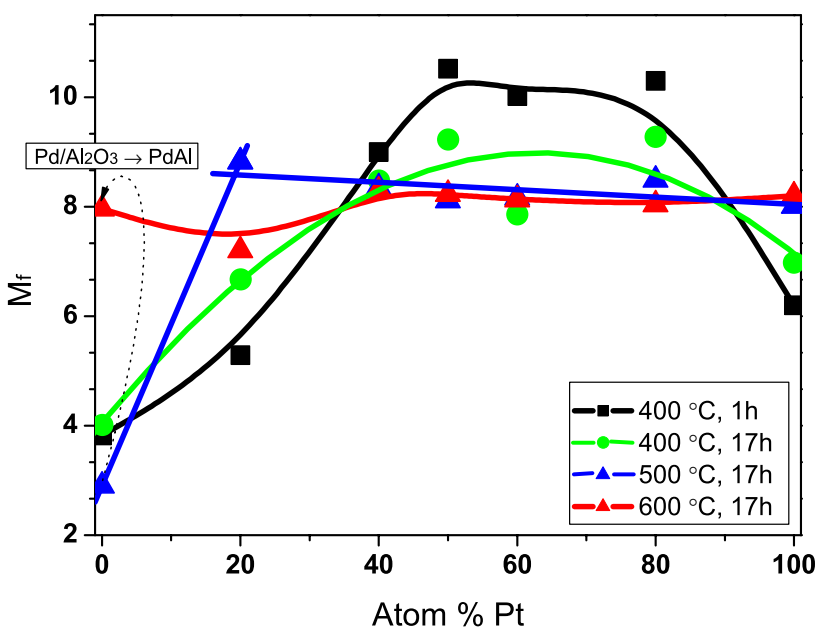

Fig. 3 Variations of $M_{f}$ parameter with $\mathrm{Pd}-\mathrm{Pt}$ alloy composition. $n$-Hexane conversion at $291{ }^{\circ} \mathrm{C}$

4). As mentioned in our previous publication [3], the main reactions occurring during $\mathrm{n}$-hexane hydroconversion at the reaction temperatures $\leq 291{ }^{\circ} \mathrm{C}$ were hydrogenolysis and isomerization (dominant reaction). Since the variations in isomerization selectivity were previously discussed, it would be now rather impractical to spend time on discussion of changes in the overall selectivity for hydrogenolysis. Negligible amounts of isobutane and isopentane in products (Tables 5-8 (ESM)) allow to treat both reaction pathways (hydrogenolysis and isomerization) as independent and discuss the relationship between the rate of $n$-hexane hydrogenolysis $\left(\mathrm{TOF}_{\text {hydrg }}\right.$ ) and the composition of Pd-Pt alloys. To this aim Fig. 1 collects the relevant data. It is seen that, 
Fig. 4 n-Hexane hydrogenolysis pattern expressed in terms of omega factors (defined in text) for $1 \mathrm{wt} \% \mathrm{Pd}-\mathrm{Pt} / \mathrm{Al}_{2} \mathrm{O}_{3}$ catalysts subjected to different reduction conditions. The effect of nominal bimetal composition on the demethylation/internal splitting ratio, calculated as $\left(\omega_{1} /\right.$ $\left(\omega_{2}+\omega_{3}\right): \mathbf{a}$ after reduction at $400{ }^{\circ} \mathrm{C}$ for $1 \mathrm{~h}, \mathbf{b}$ after reduction at $400{ }^{\circ} \mathrm{C}$ for $17 \mathrm{~h}, \mathbf{c}$ after reduction at $500{ }^{\circ} \mathrm{C}$ for $17 \mathrm{~h}, \mathbf{d}$ after reduction at $600{ }^{\circ} \mathrm{C}$ for $17 \mathrm{~h}$ (a)

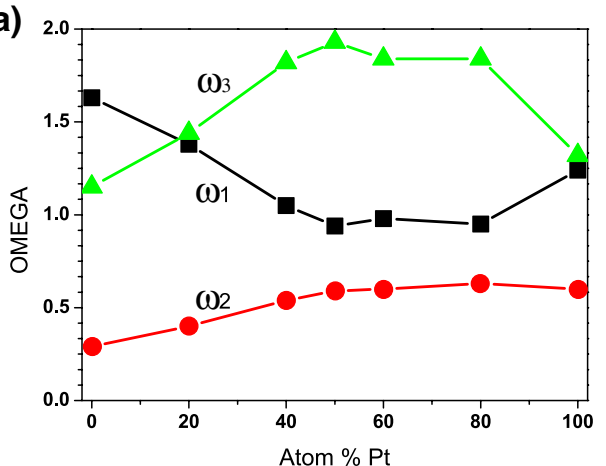

(c)

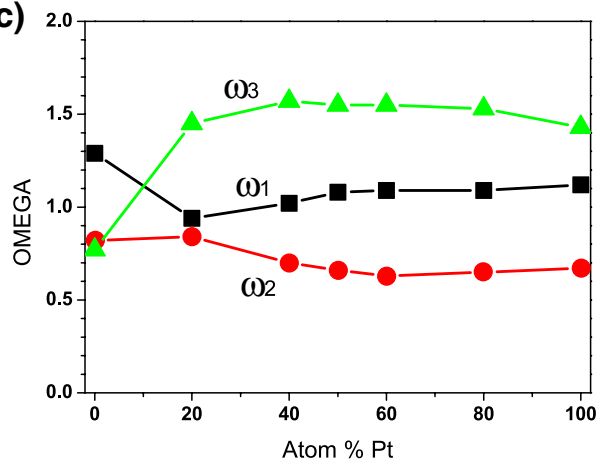

(b)

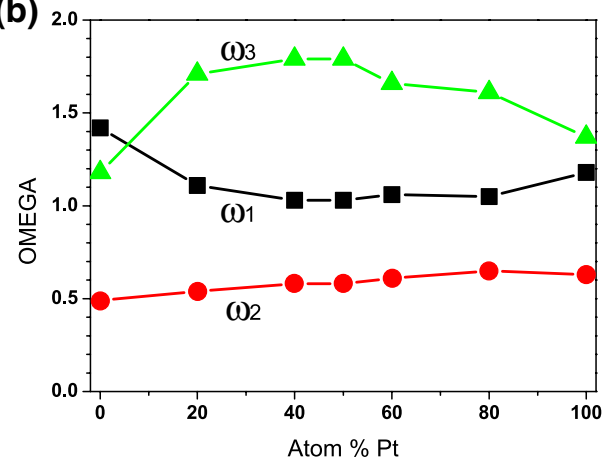

(d)

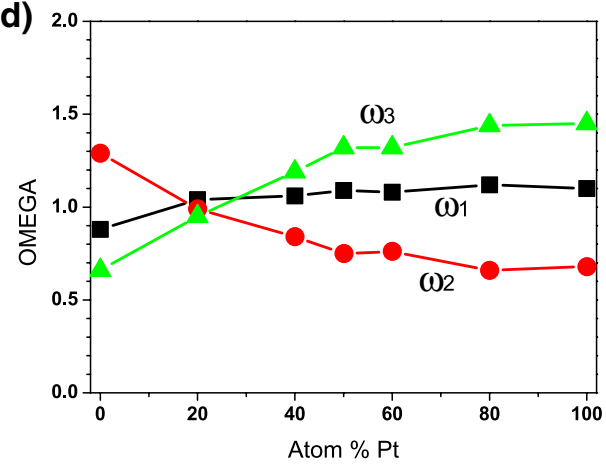

irrespective of the catalyst' reduction conditions, $\mathrm{Pt} 100$ was much more active than the rest of $\mathrm{Pd}-\mathrm{Pt} / \mathrm{Al}_{2} \mathrm{O}_{3}$ catalysts. A concave shape of this relation (Fig. 1) is in agreement with our previous conclusion [3] about a considerable surface enrichment of Pd-Pt alloys in palladium (inset in Fig. 1). This is also in line with Wu et al. [16], who concluded that for neopentane hydroconversion on silica-supported Pd-Pt catalysts, the reaction rates and selectivities were determined predominantly by Pt with little contribution from Pd surface species.

It appeared interesting to search for the relation between $\ln \mathrm{A}\left(\mathrm{A}=\mathrm{TOF}_{\mathrm{o}}\right)$ and $\mathrm{E}_{\mathrm{app}}$ (apparent energy of activation) for differently pretreated $\mathrm{Pd}-\mathrm{Pt} / \mathrm{Al}_{2} \mathrm{O}_{3}$ catalysts, the compensation effect which was quite often reported for alkane hydrogenolysis reactions, especially for ethane hydrogenolysis [7, 17]. We were encouraged by the results of Bond [18], who constructed a common compensation plot for the hydrogenolysis of ethane on platinum and palladium catalysts, based on the results of Sinfelt [6], inset in Fig. 2. We used the values of apparent energies of activation, which ranged between 95 and $158 \mathrm{~kJ} / \mathrm{mol}$ (Tables 1-4, (SM)). It must be recalled that the hydrogenolysis rates measured for $\mathrm{Pd}$-rich, $\mathrm{Pd}-\mathrm{Pt} / \mathrm{Al}_{2} \mathrm{O}_{3}$ catalysts were found very low, especially for the lowest temperature of reaction $\left(252{ }^{\circ} \mathrm{C}\right.$, Tables 1-4 (ESM)). Therefore, due to uncertainties in estimating TOF values at this temperature, points in the compensation plot constructed from the experimental data for the $\mathrm{Pd}-\mathrm{Pt} / \mathrm{Al}_{2} \mathrm{O}_{3}$ catalysts reduced at $400{ }^{\circ} \mathrm{C}$ for $1 \mathrm{~h}$, and at $600{ }^{\circ} \mathrm{C}$ for $17 \mathrm{~h}$ (ln TOF vs. $\mathrm{E}_{\text {app }}$, Fig. 2) are somewhat scattered. Nevertheless, two things seem worth mentioning. First, a common compensation plot for the catalysts of different $\mathrm{Pd}: \mathrm{Pt}$ ratio suggests that the mechanism of $n$-hexane hydrogenolysis is generally similar, confirming analogous speculations based on the common compensation plot for silica-supported Pt and Pd catalysts shown in the inset in Fig. 2). Second, the departure of one experimental point (for Pd reduced at $600^{\circ} \mathrm{C}$ ) for the compensation plot indicates that the $\mathrm{Pd} 100 / \mathrm{Al}_{2} \mathrm{O}_{3}$ experiences big changes after reduction at very high temperature. Our recent work [19] showed that palladium interacts with the alumina support and transforms, even if not fully, into a $\mathrm{Pd}-\mathrm{Al}$ alloy.

As far as the catalytic characteristics mentioned above are not unexpected in the light of our previous findings, variations in the "hydrogenolysis pattern", i.e. distribution of hydrogenolysis products, affected by changes in the composition of a catalytically active phase $(\mathrm{Pd}-\mathrm{Pt})$ and catalyst's pretreatment, are far more interesting.

Primary analysis of hydrogenolysis products of n-hexane hydroconversion established that the fragmentation factor, $\zeta$, which characterizes the depth of hydrogenolysis as the number of fragment molecules $(i<n)$ per molecule of $\mathrm{C}_{\mathrm{n}} \mathrm{H}_{2 \mathrm{n}+2}$ alkane split up [10]:

$\zeta=\frac{\sum_{i=1}^{n-1} C_{i}}{\sum_{i=1}^{n-1}\left(\frac{i}{n}\right) C_{i}}$

was for all $\mathrm{Pd}-\mathrm{Pt} / \mathrm{Al}_{2} \mathrm{O}_{3}$ samples $2.059 \pm 0.102$ (standard deviation), for $291{ }^{\circ} \mathrm{C}$, i.e. the highest reaction temperature, 
in consistency with the single bond splitting characteristics of monometallic palladium and platinum catalysts $[9$, 10]. This result obtained at a low conversion of $n$-hexane $(<5 \%$, in most cases $<2 \%)$ simplifies further discussion on the effect of Pd-Pt alloy composition on the hydrogenolysis pattern because the contribution of secondary products is insignificant.

As mentioned in the Introduction, palladium and platinum show different hydrogenolysis patterns. On palladium the major hydrogenolysis reaction is terminal demethylation, whereas for platinum, apart from demethylation, the secondary-secondary $\mathrm{C}-\mathrm{C}$ bond rupture becomes important $(10,11,20]$. A 'fission parameter' $M_{f}$ appears a good measure for treating differences in a quantitative way [21]:

$M_{f}=\frac{\sum_{i=2}^{n-1} C_{i}(n-i)}{C_{1}}$

Its value is one for terminal demethylation, while $M_{f}<1$ with multiple and $M_{f}>1$ with random (so also with internal) splitting. Although this parameter is influenced by reaction conditions (e.g. reaction temperature, $\mathrm{H}_{2}$-to-alkane pressure ratio), much higher than in the case of palladium, values of $M_{f}$ for platinum catalysts reflect the generally accepted view regarding the difference in the catalytic behavior of both metals. Considering similar reaction conditions, the $M_{f}$ values for different forms of Pd catalysts were reported as close to $2[22,23]$ whereas $M_{f}$ for Pt catalysts was usually much higher, often approaching a level of ca. fivefold higher [22, 24].

Figure 3 shows results obtained for $n$-hexane hydrogenolysis over $\mathrm{Pd}-\mathrm{Pt} / \mathrm{Al}_{2} \mathrm{O}_{3}$ catalysts prereduced at different conditions. For the monometallic catalysts, the effect of reduction temperature is not large: for $1 \mathrm{wt} \% \mathrm{Pt} / \mathrm{Al}_{2} \mathrm{O}_{3} M_{f}$ changes between 6 and 8 , whereas for $1 \mathrm{wt} \% \mathrm{Pd} / \mathrm{Al}_{2} \mathrm{O}_{3}$, with noticeable exception for the pretreatment at $600{ }^{\circ} \mathrm{C}$, it is between 3 and 4 . For the bimetallic samples reduced at $400{ }^{\circ} \mathrm{C}$ for $1 \mathrm{~h}$ and $17 \mathrm{~h}$ one observes a distinct maximum in the $M_{f}$ for ca. 60 at. \% Pt. The increase of the temperature of catalyst reduction "flattens" this maximum, finally leading to the situation where nearly all Pd-Pt catalysts show a similar hydrogenolysis pattern after reduction at $600{ }^{\circ} \mathrm{C}$. It is difficult to suggest specific reasons for this effect, however one possibility would be that highly unsaturated metal sites (like edge atoms) are responsible for internal splitting and plane metal atoms are better for terminal demethylation. Such supposition is in line with the hydrogenolysis behavior of unsupported palladium catalysts (powders [10] and single crystals [23]) which generally show lower values of $M_{f}$ parameter compared to that exhibited by highly dispersed Pd systems (this work). The decrease of $M_{f}$ for $\mathrm{Pd} 100$ after reduction at $500{ }^{\circ} \mathrm{C}$, from $\sim 4$ to $\sim 3$ (Fig. 3) confirms our hypothesis, especially, when we recall recently found observation that $\mathrm{Pd}$ nanocrystals for samples reduced at $400{ }^{\circ} \mathrm{C}$ for $1 \mathrm{~h}$ were irregular in shape and exhibited highly distorted crystal lattice, in the opposition to nanocrystals for the sample reduced at higher temperatures. The latter nanocrystals had near perfect crystallinity and were terminated by the $\{011\}$ type facets (Fig. 8 in Supplementary Material for [19]). The most remarkable change is observed for the monometallic $\mathrm{Pd} 100 / \mathrm{Al}_{2} \mathrm{O}_{3}$ catalyst which shows $M_{f}$ close to 8 , characteristic for platinum catalysts (Fig. 3). Obviously, such change is in sharp conflict with the above interpretation and will be discussed a little later.

A closer look into the hydrogenolysis behavior can be obtained from the so-called reactivity factor $(\omega)$, describing the pattern of hydrogenolysis of any $\mathrm{C}-\mathrm{C}$ bond in $\mathrm{n}$-hexane chain. This factor, defined by Leclercq et al. [25] is expressed as:

$$
\omega=\frac{\text { Actual rate of rupture }}{\text { Expected rate of rupture (random fission) }}
$$

In the case of n-hexane hydrogenolysis, $\omega_{1}, \omega_{2}$ and $\omega_{3}$ stand for the rupture of $\mathrm{H}_{3} \mathrm{C}-\mathrm{C}_{5} \mathrm{H}_{11}, \mathrm{C}_{2} \mathrm{H}_{5}-\mathrm{C}_{4} \mathrm{H}_{9}$ and $\mathrm{C}_{3} \mathrm{H}_{7}-\mathrm{C}_{3} \mathrm{C}_{7}$ bonds, respectively.

Figure 4 shows respective omega factors for all tested catalysts subjected to hydrogen reduction at different temperatures (a, b, c and d). It is observed that $n$-hexane hydrogenolysis patterns of the monometallic $\mathrm{Pd} 100 / \mathrm{Al}_{2} \mathrm{O}_{3}$ and $\mathrm{Pt} 100 / \mathrm{Al}_{2} \mathrm{O}_{3}$ catalysts do not differ from each other, so much as it would be expected from earlier studies [10, $20,22]$, where the demethylating character of palladium contrasted with an internal splitting of hexane, characteristic for platinum. For instance, Paál and Tétényi [10] give respective omega values for Pd black catalyst: $\omega_{1}=2.61$, $\omega_{2}=0.3$, and $\omega_{3}<0.05$, clearly indicating a dominance of terminal over internal splitting behavior. We believe that this difference would be due to some interactions between palladium and alumina, generated by a high temperature reduction. Our recent work (Fig. 2 in [19]) shows that the $\omega_{1} /\left(\omega_{2}+\omega_{3}\right)$ ratio, which reflects the importance of demethylation over internal rupture, was gradually diminished with the increase of the temperature of $\mathrm{Pd} 100 / \mathrm{Al}_{2} \mathrm{O}_{3}$ reduction. The respective omega values for this catalyst reduced at $300{ }^{\circ} \mathrm{C}$ were: $\omega_{1}=1.98, \omega_{2}=0.21$ and $\omega_{3}=0.61$, being more closer to the respective values obtained for Pd black [10], indicating a more stronger demethylation character of palladium.

Figure $4 \mathrm{a}$ and $\mathrm{b}$ show that in line with the results of $M_{f}$, changes in the omega parameters vs. alloy composition indicate that the "more internal" bond rupture character of platinum is not only retained for a majority of $\mathrm{Pd}-\mathrm{Pt}$ bimetallic catalysts reduced at $400{ }^{\circ} \mathrm{C}$, but it is even considerably enhanced. The increase of the $\omega_{3}$ factor results 
from an increased amount of propane in hydrogenolysis product, Tables 5 and 6 (ESM). It should be recalled that higher amounts of propane in products of $n$-hexane conversion over bimetallic $\mathrm{Pd}-\mathrm{Pt} / \mathrm{Al}_{2} \mathrm{O}_{3}$ catalysts were also observed by others [26], but that finding was not subjected to discussion. We believe that this synergistic effect would be interpreted by accepting variations in the electronic structure of Pd-Pt alloys. There is evidence that $\mathrm{Pt}$ atoms in highly dispersed $\mathrm{Pd}-\mathrm{Pt}$ alloy catalysts are electron-deficient, due to electron transfer from Pt to $\mathrm{Pd}$ [2, 27-29]. Electropositive character of Pt atoms (in $\mathrm{Pd}-\mathrm{Pt}$ ) implies their weaker bonding of such adsorbates like CO. Such conclusion is in line with the results of IR study of $\mathrm{CO}$ adsorption on $\mathrm{Pd}-\mathrm{Pt} / \mathrm{SiO}_{2}$ catalysts [30] and observation that all adsorbed $\mathrm{CO}$ bands were shifted to higher frequencies by about $10 \mathrm{~cm}^{-1}$, compared to the positions of respective $\mathrm{CO}$ bands for $\mathrm{Pt} / \mathrm{SiO}_{2}$. The weakening of the CO-metal bond implies also a weakening of the alkane-metal bond. Such parallelism was invoked by Childers et al. [31], who even proposed a linear relationship between the energies of $\mathrm{CO}$ and hydrocarbon adsorption in the form: $\mathrm{E}_{\mathrm{CO}, \text { ads }}=0.60 \mathrm{E}_{\mathrm{CH} 3 \text {,ads }}-0.09$ (energies in $\mathrm{eV}$ ). It appears that the weakening of the alkane-metal bonding would lead to an increased internal rupture of n-hexane at the expense of its terminal demethylation. This may be realized by migration of the metal-hexane bond along the molecule chain. Actually, Sinfelt [7] argued that the carbon-metal double bonds (invoked in a large variety of proposed mechanisms of alkane hydrogenolysis on metals, reviewed by Maire and Garin [32], could shift readily from a terminal carbon atom to an internal one along the alkane chain making use of a variable valency of surface atoms. In our case, such specific pairs of metal atoms would be composed of $\mathrm{Pt}^{\sigma+}$ atoms and zerovalent metal species in Pd-Pt alloy surface. In addition, a weaker, compared to terminal, internal $\mathrm{C}-\mathrm{C}$ bonds in $\mathrm{n}$-hexane molecule would be subjected to a more preferential splitting $\left(\mathrm{D}_{298}^{\mathrm{o}}=368.4 \pm 6.3 \mathrm{~kJ} / \mathrm{mol}\right.$ for $\mathrm{CH}_{3} \mathrm{C}_{5} \mathrm{H}_{11}$ versus $\mathrm{D}_{298}^{\mathrm{o}}=366.1 \pm 3.3 \mathrm{~kJ} / \mathrm{mol}$ for $\mathrm{C}_{3} \mathrm{H}_{7}-\mathrm{C}_{3} \mathrm{H}_{7}$, [33]. Figure 3 (a and $b$ ) shows that indeed the $\omega_{3}$ factor becomes increased at the expense of the $\omega_{1}$ factor, whereas the $\omega_{2}$ factor experiences only minor changes. Zimmer et al. observed that the decrease of the hydrogen-to-hexane pressure ratios gradually increased the importance of demethylation over internal splitting on Pt black [34]. At such conditions increasing deposition of carbonaceous species makes the surface of platinum less capable for stronger reactant bonding.

It should be recalled that synergistic effects in alkane hydrogenolysis are not new and were reported in the past. For example, in testing platinum-rhenium single crystal surfaces in the hydrogenolysis of ethane, Godbey et al. [35] found that although the $\operatorname{Re}(0001)$ surface was two orders of magnitude more active than the $\operatorname{Pt}(111)$ surface, yet a bimetallic surface of the stoichiometry $\mathrm{Re}_{2} \mathrm{Pt}$ was found to be the most active surface for ethane hydrogenolysis-about one order of magnitude more active than the $\operatorname{Re}(0001)$ surface. This result suggested that an electronic interaction exists between platinum and rhenium metals that strongly influences the catalytic behavior.

Both changes in $M_{f}$ and omega factors show that the aforementioned synergistic effect is gradually weakened by increasing the temperature of catalyst's reduction. As far as the temperature of catalyst's reduction has not reached $600{ }^{\circ} \mathrm{C}$, the $\omega_{3}$ factor for a majority of Pd-Pt catalysts is at the level characteristic of platinum (Fig. 4c). However, the reduction at $600{ }^{\circ} \mathrm{C}$ (Fig. 4d) clearly changes the relation between the $\omega_{3}$ factor and Pd-Pt alloys concentration which now it smoothly decreases with palladium introduction to platinum. The $\omega_{1}$ factor does not apparently change with Pd-Pt alloy composition. It means that $n$-hexane demethylation, characteristic for palladium catalysts, is not regained. Instead, one observes the increase of $\omega_{2}$ with the increase of $\mathrm{Pd}$ content. This result appears striking because the rupture of $\mathrm{C}_{2} \mathrm{H}_{5}-\mathrm{C}_{4} \mathrm{H}_{9}$ bond was never favored in the case of platinum and palladium catalysts. It rather recalls the cracking behavior of acidic catalysts [36]. We believe that such behavior may result from generated $\mathrm{Pd}-\mathrm{Al}_{2} \mathrm{O}_{3}$ interactions, identified with $\mathrm{Pd}-\mathrm{Al}$ alloying, evidenced in earlier publications [37-39] and recently confirmed by us [19]. DFT calculations of small $\mathrm{Pd}_{\mathrm{n}} \mathrm{Al}_{\mathrm{m}}(\mathrm{n}+\mathrm{m} \leq 6)$ clusters showed that the values of vertical ionization potential are much higher than the values of vertical electron affinity, implying that the bimetallic PdAl clusters easily accept electrons [40]. The conclusion about an electropositive character of PdAl clusters can be drawn from other reports. The results of IR studies of $\mathrm{CO}$ adsorbed on $\mathrm{Pd} / \mathrm{Al}_{2} \mathrm{O}_{3}$ catalysts reduced at $600{ }^{\circ} \mathrm{C}$ (i.e. supposedly transformed into $\mathrm{Pd}-\mathrm{Al}$ species) [41] revealed the presence of $\mathrm{Pd}^{\mathrm{n}+}$ ions. Likewise, Rodriguez [42] argued that Pd atoms supported on A1 clusters exhibit a net positive charge. This may be a reason why such PdAl clusters are very selective in alkane isomerization [19], and, in addition, a small part of n-hexane is apparently cracked in the way more characteristic for acidic catalysts [43, 44]. Mixed Pd-Al sites would act as an electron sink (weak Lewis acid) for adsorbed n-hexane, creating electron-deficient species that can rearrange in a manner analogous to carbonium ions.

\section{Conclusions}

1. In the reaction of $n$-hexane hydrogenolysis the aluminasupported monometallic platinum catalyst showed much higher activity than $\mathrm{Pd} / \mathrm{Al}_{2} \mathrm{O} 3$ and all tested $\mathrm{Pd}-\mathrm{Pt} / \mathrm{Al}_{2} \mathrm{O}_{3}$ catalysts. The "concave-shaped" relationship between the catalytic activity of $\mathrm{Pd}-\mathrm{Pt} / \mathrm{Al}_{2} \mathrm{O}_{3}$ catalysts and bulk 
Pd-Pt composition, is reminiscent of the accepted relation between the surface and bulk compositions.

2. A compensation effect between frequency factor and apparent activation energy suggests that the reaction mechanism is similar for all Pd-Pt catalysts. Departure from the compensation plot for the monometallic $\mathrm{Pd} / \mathrm{Al}_{2} \mathrm{O}_{3}$ catalyst pretreated in hydrogen at $600{ }^{\circ} \mathrm{C}$ is not unexpected high temperature reduction $\left(\right.$ at $600{ }^{\circ} \mathrm{C}$ ) because such severe reduction conditions result in transformation into Pd-Al bimetallic alloy [19].

3. Very big change in the hydrogenolysis behavior of $\mathrm{Pd} /$ $\mathrm{Al}_{2} \mathrm{O}_{3}$ generated by high temperature reduction is also manifested by variations in the product distribution, expressed by different bond fission parameters.

4. Distribution of n-hexane hydrogenolysis products for the platinum catalyst differs from that of palladium one, showing more internal bond splitting than demethylation. However, alloying platinum with palladium enhances this effect. Reasons for the existence of this synergy are seen in the variations of the electronic structure of platinum alloyed with palladium.

Acknowledgements This work was carried out within Research Project \# 2016/21/B/ST4/03686 from the National Science Centre (NCN), Poland.

\section{Compliance with Ethical Standards}

Conflict of interest The authors declare no conflict of interest.

Open Access This article is distributed under the terms of the Creative Commons Attribution 4.0 International License (http://creativeco mmons.org/licenses/by/4.0/), which permits unrestricted use, distribution, and reproduction in any medium, provided you give appropriate credit to the original author(s) and the source, provide a link to the Creative Commons license, and indicate if changes were made.

\section{References}

1. Ponec V, Bond GC (1995) Catalysis by metals and alloys. Ch. 13. Reactions of alkanes and reforming of naphtha. Elsevier, Amsterdam

2. Lee JK, Rhee HK (1998) Sulfur tolerance of zeolite beta-supported Pd-Pt catalysts for the isomerization of n-hexane. J Catal 177:208-216

3. Radlik M, Śrębowata A, Juszczyk W, Matus K, Małolepszy A, Karpiński Z (2019) n-Hexane conversion on $\gamma$-alumina supported palladium-platinum catalysts. Adsorption 1:1-10. https://doi. org/10.1007/s10450-019-00083-9

4. Renouprez AJ, Malhomme A, Massardier J, Cattenot M, Bergeret G (2000) Sulphur resistant palladium-platinum catalysts prepared from mixed acetylacetonates. Stud Surf Sci Catal 130C:2579-2584
5. Renouprez A, Lebas K, Bergeret G (1997) A new method of direct synthesis of bimetallic phases: silica supported $\mathrm{Pd}-\mathrm{Cu}$ catalysts from mixed acetylacetonates. J Mol Catal A 120:217-225

6. Sinfelt JH (1970) Catalytic hydrogenolysis over supported metals. Catal Rev 3:175-205

7. Sinfelt JH (1973) Specificity in catalytic hydrogenolysis by metals. Adv Catal 23:91-119

8. Clarke JKA, Rooney JJ (1976) Stereochemical approaches to mechanisms of hydrocarbon reactions on metal catalysts. Adv Catal 25:125-183

9. Paál Z, Tétényi P (1982) Catalysis. specialists periodical reports, In: Bond GC, Webb G (eds.) Vol 5. The Royal Society of Chemistry, London

10. Paál Z, Tétényi P (1979) On the pattern of hydrogenolysis of hexane isomers over four group VIIIB metals. React Kinet Catal Lett 12:131-137

11. Gault FG (1981) Mechanisms of skeletal isomerization of hydrocarbons on metals. Adv Catal 30:1-95

12. Ichikawa S, Poppa H, Boudart M (1985) Disproportionation of $\mathrm{CO}$ on small particles of silica-supported palladium. J Catal 91:1-10

13. Rachmady V, Vannice MA (2000) Acetic acid hydrogenation over supported platinum catalysts. J Catal 192:322-334

14. Rousset JL, Bertolini JC, Miegge P (1996) Theory of segregation using the equivalent-medium approximation and bond-strength modifications at surfaces: application to fcc Pd-X alloys. Phys Rev B 53:4947-4957

15. Kościelski T, Karpiński Z (1978) Neopentane isomerization over silica-supported Pt-Pd alloys. Z phys Chem NF 111:125-128

16. Wu T, Childers DJ, Gomez C, Karim AM, Schweitzer NM, Kropf AJ, Wang H, Bolin TB, Hu Y, Kovarik L, Meyer RJ, Miller JT (2012) General method for determination of the surface composition in bimetallic nanoparticle catalysts from the L edge X-ray absorption near-edge spectra. ACS Catal 2:2433-2443

17. Bond GC, Hooper AD, Slaa JC, Taylor AO (1996) Kinetics of metal-catalyzed reactions of alkanes and the compensation effect. J Catal 163:319-327

18. Bond GC (1999) Kinetics of alkane reactions on metal catalysts: activation energies and the compensation effect. Catal Today 49:41-48

19. Radlik M, Małolepszy A, Matus K, Śrębowata A, Juszczyk W, Dłużewski P, Karpiński Z (2019) Alkane isomerization on highly reduced $\mathrm{Pd} / \mathrm{Al}_{2} \mathrm{O}_{3}$ catalysts. The crucial role of $\mathrm{Pd}-\mathrm{Al}$ species. Catal Comm 123:17-22

20. Garin F, Girard P, Chaqroune A, Weisang F, Maire G (1984) In: Procedings of 8th International Congress Catalysis, Berlin, 1984, Vol. III. Activity and selectivity in isomerization of ${ }^{13} \mathrm{C}$-labeled hexanes on supported palladium-platinum alloys. Verlag Chemie, Weinheim pp 405-415

21. Matsumoto H, Saito Y, Yoneda Y (1970) Contrast between nickel and platinum catalysts in hydrogenolysis of saturated hydrocarbons. J Catal 19:101-112

22. Matsumoto H, Saito Y, Yoneda Y (1971) The classification of metal catalysts in hydrogenolysis of hexane isomers. J Catal 22:182-192

23. Ramos ALD, Kim SH, Chen P, Song JH, Somorjai GA (2000) Reaction pathway studies of $\mathrm{C}_{6}$ hydrocarbons on palladium model catalysts: effects of hydrogen/hydrocarbon ratio, molecular structure, surface structure and temperature. Catal Lett 66:5-11

24. Paál Z, Groeneweg H, Paál-Lukacs J (1990) Transformations of n-hexane over EUROPT-1: fragments and $C_{6}$ products on fresh and partially deactivated catalyst. Chem Soc Faraday Trans 86:3159-3166

25. Leclercq G, Leclercq L, Maurel R (1977) Hydrogenolysis of saturated hydrocarbons. III. Selectivity in hydrogenolysis of various aliphatic hydrocarbons on platinum/alumina. J Catal 50:87-97 
26. Contreras JJ, Ferreira JM, Fuentes S, Gómez R (1977) n-Hexane hydrogenolysis on bimetallic platinum-palladium catalysts. React Kinet Catal Lett 7:373-378

27. Matsubayashi N, Yasuda H, Imamura M, Yoshimura Y (1998) EXAFS study on Pd-Pt catalyst supported on USY zeolite. Catal Today 45:375-380

28. Yoshimura Y, Toba M, Matsui T, Harada M, Ichihashi Y, Bando KK, Yasuda H, Ishihara H, Morita Y, Kameoka T (2007) Active phases and sulfur tolerance of bimetallic Pd-Pt catalysts used for hydrotreatment. Appl Catal A Gen 322:152-171

29. Yu Y, Fonfé B, Jentys A, Haller GL, van Veen JAR, Gutiérrez OY, Lercher JA (2012) Bimetallic Pt-Pd/silica-alumina hydrotreating catalysts-Part I: physicochemical characterization. J Catal 292:1-12

30. Grill CM, Gonzalez RD (1980) Infrared study of the adsorption of CO and NO on silica-Supported Pd and Pt-Pd. J Phys Chem 84:878-882

31. Childers D, Saha A, Schweitzer N, Rioux RM, Miller JT, Meyer RJ (2013) Correlating heat of adsorption of CO to reaction selectivity: geometric effects vs electronic effects in neopentane isomerization over Pt and Pd catalysts. ACS Catal 3:2487-2496

32. Maire GLC, Garin FG (1984) Catalysis - science and technology, Vol. 6, series eds. In: Anderson JR, Boudart M, Metal catalyzed skeletal reactions of hydrocarbons on metal catalysts. Springer, Berlin, pp. 161-226

33. (2017) In: Handbook of Chemistry and Physics 98th Edition 2017-2018, editor-in-chief J.R. Rumble CRC Press, Taylor and Francis, Boca Raton, p 9-79

34. Zimmer H, Dobrovolszky M, Tétényi P, Paál Z (1986) Hydrogen control of platinum-catalyzed skeletal reactions of alkanes: selectivities and surface species. J Phys Chem 90:4758-4764

\section{Affiliations}

\section{Monika Radlik ${ }^{1} \cdot \mathrm{Krzysztof} \mathrm{Matus}^{2} \cdot$ Zbigniew Karpiński $^{1}$}

Monika Radlik

m.radlik@uksw.edu.pl

1 Faculty of Mathematics and Natural Sciences, Cardinal Stefan Wyszyński University in Warsaw, ul. Wóycickiego 1/3, 01938 Warsaw, Poland
35. Godbey DJ, Garin F, Somorjai GA (1989) The hydrogenolysis of ethane over $\operatorname{RePt}(111)$ and $\mathrm{PtRe}(0001)$ bimetallic crystal surfaces. J Catal 117:144-154

36. Song JH, Chen P, Kim SH, Somorjai GA, Gartside RJ, Dautzenberg FM (2002) Catalytic cracking of $n$-hexane over $\mathrm{MoO}_{2}$. J Mol Catal A 184:197-202

37. Kępiński L, Wołcyrz M, Jabłoński JM (1989) Effect of high-temperature reduction on carburization of alumina-supported palladium: evidence for palladium-aluminium alloy formation. Appl Catal 54:267-276

38. Juszczyk W, Łomot D, Karpiński Z, Pielaszek J (1995) Neopentane conversion over $\mathrm{Pd} / \gamma-\mathrm{Al}_{2} \mathrm{O}_{3}$. Catal Lett 31:37-45

39. Penner S, Jenewein B, Hayek K (2007) Pd-Al interaction at elevated temperatures: a TEM and SAED study. Catal Lett 113:65-71

40. Bouderbala W, Boudjahem AG (2014) First-principles calculations of small $\mathrm{Pd}_{\mathrm{n}} \mathrm{Al}_{\mathrm{m}}(\mathrm{n}+\mathrm{m} \leq 6)$ clusters. Phys B 454:217-223

41. Juszczyk W, Karpiński Z, Ratajczykowa I, Stanasiuk Z, Zieliński J, Sheu LL, Sachtler WMH (1989) Characterization of supported palladium catalysts. III. $\mathrm{Pd} / \mathrm{Al}_{2} \mathrm{O}_{3}$. J Catal 120:68-77

42. Rodriguez JA (1996) Electronic and chemical properties of Pt, Pd and Ni in bimetallic surfaces. Surf Sci 345:347-362

43. Surjo I, Christoffel EG (1979) Kinetics of simultaneous isomerization and cracking of n-hexane over $\mathrm{Pt}_{\mathrm{Al}_{2} \mathrm{O}_{3}}$. J Catal 60:133-139

44. Smirniotis PG, Ruckenstein E (1993) Comparison between zeolite $\beta$ and $\gamma-\mathrm{Al}_{2} \mathrm{O}_{3}$ supported $\mathrm{Pt}$ for reforming reactions. J Catal 140:526-542

Publisher's Note Springer Nature remains neutral with regard to jurisdictional claims in published maps and institutional affiliations.

2 Institute of Engineering Materials and Biomaterials, Silesian University of Technology, ul. Konarskiego 18A, 44100 Gliwice, Poland 